\title{
MENAPAKI FEMINISME GEOGRAFI PASCA POSITIVISTIK
}

\author{
Oleh: \\ Hastuti \\ Jurusan Pendidikan Geografi FIS UNY \\ hastuti@uny.ac.id
}

\begin{abstract}
Abstrak
Geografi maskulin telah mendominasi pemikiran geografi hingga dekade 90 an ditengah gegap gempitanya paham positivistik. McDowell dan Doreen (1996), bahwa ilmu spasial yang cenderung positivistik didukung oleh rasionalitas maskulin. Kajian geografis seharusnya menolak rasionalitas demikian bahkan dituntut untuk sensitif terhadap distribusi hubungan kekuasaan dalam proses penelitian. Geografi positivistik diakui memiliki kelemahan untuk menjelaskan tentang aktifitas maupun perilaku sosial, budaya, dan ekonomi manusia secara detail. Manusia adalah makhluk kompleks yang tidak selalu berpikir dan berperilaku linier sehingga dengan mudah dibuat sebagai model sebagaimana sering diterapkan pada pemikiran positivistik. Geografi yang menfokuskan kajian tentang manusia mengusulkan untuk adopsi analisis geografis yang sensitif agar mampu menangkap kehidupan manusia yang kompleks secara mendalam. Pemikiran postpositivistik dalam studi kualitatif menjadi alternatif analisa yang didukung oleh geograf feminis.
\end{abstract}

Kata kunci: feminisme, geografi, positivistik

\begin{abstract}
Masculine geography has dominated the thinking of geography until the 90's amidst the rousing of positivistic. McDowell and Doreen (1996) explain that spasial science tend to be positivistic supported by masculine rationality. A geographic study is supposed to reject this rationality, moreover it should be sensitive to the distribution of power relations in the research process. Positivistic geography, in fact, has weaknesses to explain human activities or social behavior, cultural, and economic in detail. Humans are complex creatures that do not always think and behave in a linear way, therefore they are easily made as a model as it is often applied in positivistik thinking. Geography that focuses on human studies proposes for adoption of sensitive geographical analysis in order to be able to capture complex human life thoroughly. Post-positivistic thinking in qualitative studies can be an alternative analysis which is supported by feminist geographers.
\end{abstract}

Keywords: feminism, geography, positivistic

\section{PENDAHULUAN}

Philosophy bertujuan mencapai kebijaksanaan guna memperoleh kebenaran dan kejelasan ketika mengambil keputusan tentang apa yang akan dilakukan ketika memahami kenyataan secara utuh, baik, benar, dan jelas. Manusia diajarkan untuk mencintai dialog kritis melalui penalaran dan pemikiran. Dialog kritis dalam memperoleh kebenaran, diterapkan dengan pendekatan dalam keilmuan yang dikenal melalui positivisme. Positivisme sebagai prinsip ilmiah dan metode keilmuan dengan objek kajian alam diterapkan dalam geografi. Geografi memiliki objek kajian manusia dan alam, 
pada era ini positivisme menjadi pendekatan yang populer dalam geografi terutama pasca revolusi kuantitatif (Whynne dan Hammond, 1979).

Geografi masih memperdebatkan payung keilmuan yang lebih pas terutama pada tataran epistemologi keilmuan. Questioning Geography Fundamental Debate yang dirangkum oleh Castree, N; Rogers,A; dan Sherman, D (2005), menjadi bukti masih terjadinya perdebatan dalam geografi hingga millenium kedua. Pemikiran induktif dan deduktif dalam geografi menjadi jalur yang membidani lahirnya penelitian dengan pendekatan kuantitatif dan kualitatif, keduanya sebagai pilar disiplin geografi. Pemikiran deduktif melahirkan geografi kuantitatif mengacu pada positivistik.

Proses sosial yang meliputi aktifitas manusia dimuka bumi menolak issue-isu politik, sosial, religi, kesenjangan antar kelompok masyarakat sebagai kenyataan yang ada pada kehidupan manusia. Pendekatan positivistik dianggap kurang mampu untuk analisis kenyataan variasi dan kompleksitas kehidupan manusia yang menyertai proses sosial. Kehidupan manusia sebagai makhluk rasional namun melekat kondisi irasionalitas, ideologi, dengan keunikan yang dimiliki meliputi kondisi sosial, budaya, politik, dan religi, bahkan perilaku dalam menanggapi lingkungan alam dan lingkungan manusia lainnya memiliki kompleksitas dan keunikan-keunikan. Kondisi ini cenderung sulit dianalisa apabila secara murni diterapkan pendekatan positivistik mengingat pendekatan tersebut lebih mengedepankan generalisasi sebagai kepanjangan analisa kuantitatif.

\section{POSITIVISTIK IDENTIK “DEDUKTIF KUANTITATIF”}

Positivistik dalam geografi dianggap gagal menjelaskan proses sosial dimuka bumi, bahkan cenderung meminggirkan isu politik, sosial, religi, dan kesenjangan antar kelompok masyarakat. Manusia dianggap rasional tanpa irasionalitas dalam mengembangkan ideologi, sehingga setiap membuat keputusan diyakini masuk akal dan logis secara utuh. Mendasarkan pemahaman tersebut kemudian dideskripsikan dan dianalogkan dalam pemikiran geografi menggunakan model sederhana yang melahirkan generalisasi. Pendekatan positivistik dalam geografi sudah dikenal sekitar tahun 1950 an sejak dikenalkan analisis spasial yang dikembangkan dari pemikiran nomotetik. Pemikiran nomotetik sebagai cikal bakal positivistik telah berhasil menggantikan ideografik yang dianggap sebagai tradisi geografi dalam jangka waktu yang berlangsung lama. Paradigma positivistik dianggap bertentangan dengan pendekatan yang telah menjadi tradisi dalam geografi seperti geografi behaviourial, geografi humanistik, dan pendekatan radikal termasuk Marxisme dan feminisme. Pemikiran positivistik kemudian digeser pada era postpositivistik yang banyak dianut oleh kelompok feminisme dan populer sebagai geograf feminis. Berkembangnya geografi feminisme dikuatkan dengan pendapat Stuart Aitken dan Gill Valentine (2006):

A paradigmatic approach to geography begins in the 1950s when positivistic spatial science emerged to challenge and supersede the regional tradition in geography. In turn the positivist paradigm is understood to have been overturned in the 1970s by other approaches such as behaviourial geography, humanistic geography and radical approaches including Marxism 
and feminisme. In the 1990s a paradigmatic perspective would understand poststructuralism as displacing these ways of thinking.

Geografi kuantitatif yang banyak dianut dalam geografi saat ini (terutama geografi fisik meskipun geografi manusia juga mengikuti paham ini) cenderung mengacu pada pendekatan positivistik. Geografi fisik memiliki objek kajian yang menekankan pada aspek alam lebih mudah dilakukan analisis dengan pendekatan positivistik mengingat alam memiliki gejala yang cenderung dapat dipastikan. Berbeda dengan aspek manusia yang memiliki dimensi kehidupan lebih kompleeks maka positivistik menjadi kurang tajam apabila dimanfaatkan unttuk analisis gejala dan perilaku manusia di muka bumi. Ironis, bahwa positivistik yang mendominasi dalam banyak analisis geografi terutama sejak revolusi kuantitatif melanda pengembangan geografi, justru pendekatan ini dianggap gagal ketika menjelaskan proses sosial. Pendekatan positivistik dianggap kurang mampu untuk analisis kenyataan variasi dan kompleksitas kehidupan manusia yang menyertai proses sosial. Kehidupan manusia sebagai makhluk rasional namun melekat kondisi irasionalitas, ideologi, dengan keunikan yang dimiliki meliputi kondisi sosial, budaya, politik, dan religi, bahkan perilaku dalam menanggapi lingkungan. Keunikan ini sulit dianalisa apabila secara murni diterapkan pendekatan positivistik yang mengedepankan generalisasi. Positivistik kurang lengkap apabila digunakan untuk menjelaskan tentang manusia sebagai makhluk yang kompleks, unik, dan rumit dalam berperilaku, bahkan tak selamanya selalu konsisten perilakunya. Geografi humanistik menjadi alternatif pemikiran untuk menterjemahkan perilaku manusia secara detail.

Geografi humanistik mengusulkan dilakukan adopsi dalam penelitian geografi agar lebih peka untuk menangkap kompleksitas kehidupan manusia secara mendalam yang dilakukan dalam studi kualitatif didukung oleh pemikiran geografi feminisme. Mc Dowell dan Massey (1996), bahwa ilmu spasial yang cenderung positivistik didukung oleh sebuah rasionalitas maskulin, kajian geografis harus menolak rasionalitas dan dituntut untuk sensitif terhadap hubungan kekuasaan dalam proses penelitian. Apa yang mungkin bermanfaat dalam pengembangan geografi untuk jangka panjang adalah upaya pengembangan geografi sebagai ilmu spasial yang lebih kritis secara filosofi tanpa harus menganggap atau mengunggulkan pendekatan tertentu termasuk pendekatan positivistik.

Geografi kuantitatif yang banyak dianut dalam geografi saat ini (terutama geografi fisik meskipun geografi manusia juga mengikuti paham ini) mengacu pada pendekatan positivistik. Meskipun diakui bahwa pendekatan positivistik yang mendominasi dalam banyak analisis geografi terutama pasca revolusi kuantitatif dalam pengembangan keilmuan geografi pendekatan ini dianggap gagal untuk menjelaskan proses sosial. Geografi menggunakan pendekatan positivistik dengan demikian kurang lengkap apabila digunakan untuk menjelaskan tentang manusia sebagai makhluk yang kompleks, unik, berperilaku yang tak sederhana, serta tak selamanya selalu konsisten perilakunya dengan lingkungan bervariasi. 
Johnston (2000) mengemukakan pengembangan ilmu dalam geografi dilakukan melalui kajian empiris, positivistik, humanistik, dan strukturalis;

a. Empiris bahwa epistemologi dilakukan melalui penelusuran atau penelitian tentang keberadaan objek yang ada dan dapat dibuktikan keberadaannya dengan metodologi guna mempresentasikan hasil penelitiannya.

b. Positivistik penjabaran epistemologi dimana pengetahuan diturunkan atas dasar percobaan dari kenyataan dan fakta guna memastikan kebenaran yang ditinjau dari berbagai tinjauan dan pakar. Pendekatan ini mempengaruhi perkembangan geografi sebagai ilmu sintesa bukan sekedar mengidentifikasi informasi yang terjadi di permukaan bumi.

c. Humanistik, epistemologi sebagai sumber pengetahuan atas dasar subjektivitas dan individual dengan telaah ontologi yang memberikan penalaran tentang keberadaan objek kajian. Pendekatan humanistik dalam geografi diartikan bahwa dalam memahami geosfer merupakan sinergi, interpretasi dan imaginasi setiap individu.

d. Strukturalis banyak dipergunakan untuk menjelaskan fenomena yang bersifat antropocentris sehingga pendekatan ini banyak diterapkan dalam kajian ilmu yang bersifat sosiologis. Pendekatan strukturalis dalam geografi memiliki nilai essensi dalam sumbangannya terhadap penelitian terkait fenomena sosial di suatu tempat, lokasi, atau ruang di muka bumi.

Revolusi kuantitatif diawali oleh pemikiran Auguste Comte (1798-1857), Comte diakui sebagai bapak positivisme, mengenalkan bahwa penelitian sosial sebelum revolusi kuantitatif dianggap kurang memiliki analogi analistis. Comte, bahwa kajian ilmiah akan lebih bermanfaat apabila berkonsentrasi pada kajian fakta, kebenaran, secara empiris tentang fenomena dengan pengumpulan data melalui metode pengamatan dan perumusan teori-teori yang dapat diuji (Unwin,1992). Secara eksplisit Stuart Aitken and Gill Valentine (2006)

Auguste Comte (1798-1857) is widely acknowledged as the father of positivism. He argued that social research prior to the nineteenth century was speculative, emotive and romantic and as a result it lacked rigour and analytical reasoning.

Kitchin (2006), mengungkapkan paham positivistic dalam kajian geografi yang memuat tentang prediksi dan penjelasan perilaku manusia secara kausal, hanya dapat dilakukan ketika data diperoleh secara objektif. Langkah kerja positivistik dilakukan melalui pembuktian hipotesis yang didahului dengan uji data secara ilmiah maupun survey menggunakan kuesioner dan pengolahan serta analisis data dituntut adanya langkah-langkah pembuktian dan perhitungan statistik. Pengujian lebih sistematis dan teliti untuk mengembangkan atau membangun teori-teori yang menjelaskan dan memprediksi tentang perilaku manusia menjadi ciri geografi positivistik.

Stuart dan Valentine (2006), Paradigma dan pendekatan geografi sesungguhnya dikenalkan ketika ilmu keruangan positvistik sebagai pilihan geografi keluar dari geografi tradisional yang condong memusatkan kajian wilayah. Berkembangnya 
paradigma positivis dipahami kembali melemah di era 1970-an seiring dengan mulai dikembangkan pendekatan-pendekatan lain seperti geografi behaviourial, geografi humanistik dan pendekatan radikal termasuk Marxisme dan feminisme. Dinamika perkembangan paradigma geografi terus bergulir hingga pada era 1990-an perspektif paradigmatik poststrukturalisme mulai mewarnai pemikiran geografi.

Penolakan pemikiran Comte terhadap pemikiran yang bersifat metafisik yakni pemikiran menyangkut makna, keyakinan, pengalaman, dan normatif karena pemikiran demikian dianggap tidak mampu untuk memperoleh jawaban yang dilakukan melalui kajian secara ilmiah. Positivistik logis berdasarkan verifikasi dan rasionalisme kritis adalah sebagai kepalsuan. Comte dalam Stuart Aitken and Gill Valentine (2006), metode ilmiah dalam tradisi ilmu yang dapat diterapkan langsung pada kajian mengenai isu sosial, terkait perilaku sosial, bahwasanya perilaku sosial harus terukur, memiliki model, dan dapat dijelaskan melalui hukum atau kaidah ilmiah. Positivistik Comte berbeda dengan pandangan rasionalisme maupun naturalisme diperkuat dengan asumsi Johnston. Johnston (1986), bahwa suatu masyarakat dalam pengambilan keputusan diidentifikasi dan diverifikasi secara objektif dan universal. Pengukuran model ini menganjurkan pada pengukuran kuantitatif yang lebih tepat sesuai fakta di lapangan (misalnya ukuran tinggi, berat, waktu, jarak, dan upah). Pengukuran dan pengujian statistik mengenai hubungan antar variabel sebagai alat untuk menguji (verifikasi) berfokus pada fakta yang dikumpulkan dari populasi yang sangat besar dapat dilakukan menggunakan sampel, dengan cara ini selanjutkan untuk melakukkan generalisasi satu fenomena.

Pendekatan deduktif merupakan kajian, dimana teori yang diperoleh dirumuskan melalui hipotesis yang telah ditetapkan dan kemudian diuji kebenarannya. Dalam kasus dimana data tidak mendukung hipotesis, teori tersebut dapat dimodifikasi, baru selanjutnya dibangun hipotesis dan data yang diperoleh kemudian dianalisa kembali. Proses demikian diadopsi, untuk membangun teori secara terstruktur dan sistematis melalui penggabungan temuan baru dan penolakan maupun uji ulang hipotesis. Apabila sampel dalam pengambilannya diperoleh tidak sempurna, sementara verifikasi dilakukan secara lengkap tidak mungkin untuk dilakukan, berarti positivisme logis (boleh jadi) akan menghasilkan kajian yang memiliki kelemahan ketika diverifikasi probabilitasnya sehingga hasilnya (tentu saja) kurang mampu dipergunakan untuk memperkuat hipotesis (Johnston, 1986). Teori yang diperoleh dengan pendekatan deduktif hanya dapat dibangun dan diakui apabila dilakukan dengan meningkatkan kekuatan probabilitas. Bahwasanya dalam paham atau aliran ini hubungan antar data yang diperoleh tidak terjadi secara kebetulan namun terdapat ketika pengambilan data terdapat persyaratan teretentu seperti adanya hubungan kausal yang sesuai fakta sehingga hipotesis dapat diuji. Kitchin, 2006 menyampaikan bahwa kajian geografi mengedepankan empirisme yang menjadi ruh dari positivistik.

Geographers were developing empiricist accounts of the world by simply accumulating facts as evidencefor generalist theories. The problem with such empiricist endeavours was that they did not distinguish between causal correlations and accidental or spurious (non-causal) associations. For 
example, environmental determinist accounts suggested that environmental conditions explicitly influenced society in a causal fashion (e.g. high ambient temperatures caused underdevelopment in tropical countries by inducing idleness among local residents)

Kitchin (2006), menyebutkan hampir semua Sistem Informasi Geografi dan penelitian geocomputational dipraktekkan dalam ilmu tata ruang, meskipun hal demikian melanjutkan tradisi empirisme; dimana fakta-fakta yang berbicara tidak selalu linier dengan analisis spasial melalui pengujian statistik. Geografi kuantitatif secara implisit adalah positivistik (atau empiris) meskipun tak selalu demikian. Secara ontologis dan epistemologis, geografi positivistik mengacu pada kajian geografis yang menggunakan data kuantitatif. Kritik terhadap geografi karena cenderung positivistik, meskipun positivisme ini secara implisit akhirnya juga dikembangkan dalam geografi manusia.

Kerja ilmiah adalah rangkaian kerja yang menggunakan prinsip-prinsip ilmiah dan penalaran, dan mencari hukum atau model matematika untuk menjelaskan geosfer. Perdebatan tentang pemikiran geografi pada ranah filosofis menempatkan geografi sebagai kajian spasial justru lemah karena mendasarkan pada empirisme yang tak selalu dilakukan dalam kajian geografi. Geografi identik dengan kajian spasial dianggap lemah dari sisi filosofi dan bangunan teori. Perdebatan dalam geografi terus berlangsung demikian pula terjadi pada positivistik yang dianggap kurang detail dalam menjelaskan fenomena perilaku dan aktifitas manusia yang menjadi sorotan utama geogafi manusia.

\section{FEMINISME GEOGRAPHY SEBUAH KENISCAYAAN}

Feminisme geografi menjadi bagian penting dalam kajian geografi manusia saat ini. Geografi feminisme sebagai salah satu aliran dalam dalam geografi manusia dengan tokoh Gillian Rose penggerak geografi feminisme. Geografi feminisme menerapkan teori, metode, dan kritik feminisme terhadap kajian lingkungan manusia, budaya, dan ruang geografis (Domosh,1999). Para ahli geografi feminisme berusaha mengungkapkan hubungan peran dan identitas jender terhadap budaya lokal dan bentang alam. Konsep geografi seperti lokasi, jarak, konektivitas, variasi keruangan, tempat, konteks, dan sekala menjadi dasar dalam pengayaan teori feminisme (Feminisme Theory) untuk menjelakan perbedaan jender antar wilayah sebagai bagian proses sosial (Dixon dan Jones, 2006). Kajian geografi feminisme dengan tekanan pada pengaruh jender yakni bagaimana perbedaan dan persamaan antara pria dan wanita terhadap akses sumber daya, kajian geografi terhadap kesejahteraan wanita pada tempat dan budaya yang berbeda, dan pembatasan jender terkait penggunaan ruang.

Perbedaan peran antara laki-laki dan perempuan didalam masyarakat dibahas di dalam berbagai teori yang secara umum dapat diklasifikasikan kepada dua kelompok. Pertama: Teori bahwa perbedaan peran laki-laki dan perempuan ditentukan oleh faktor biologis atau biasa disebut teori nature. Perbedaan ini melahirkan pemisahan tanggung jawab laki laki (hunter) dan perempuan (gatherer) dalam masyarakat modern dikenal sebagai sektor publik dan sektor domestik. Kedua: Teori bahwa perbedaan peran sosial laki-laki dan 
perempuan lebih ditentukan oleh faktor budaya atau teori nurture (Megawangi, 1997). Teori Feminisme bahwa perempuan tidak ditentukan faktor biologis melainkan faktor budaya dalam masyarakat patriarki merugikan perempuan. Kemitrasejajaran laki laki dan perempuan diusulkan sebagai ideologi dalam tata dunia baru karena selama ini kekuatan politik didominasi laki-laki. Teori sosio-biologis mencoba mengelaborasi teori nature dan nurture, bahwa faktor biologi dan sosial budaya menyebabkan laki-laki lebih unggul dari pada perempuan.

Pembaharuan kajian jender melalui metodologi geografi feminisme terus menerus diperbaharui dengan memperhatikan isu aktual dengan tetap memperhatikan konteks geografi, kajian tentang perempuan dalam konteks tempat, ruang, dan lingkungan (Rose, 1993). Pendekatan feminisme dalam geografi manusia mulai berkembang dengan kritik feminisme dalam kajian geografi. Feminisme geografi mengemukakan bahwa kebenaran didasarkan pada validitas, alternatif, penghitungan, autobiografi, dan pengalaman pribadi dalam pendekatan feminisme melibatkan pendekatan emansipasi dan pemberdayaan sehingga menjadi tulisan konvensional. Pembaharuan feminisme geografi dari pendekatan research secara tradisional menyoroti: a. pembaharuan formulasi teori tradisional, definisi, dan konsep, b. metode validitas dan asosiasi teori dikaitkan dengan isu geografi maupun isu pilihan lain. Fokus metodologi dalam penelitian geografi menggunakan metodologi feminisme merupakan salah satu cara untuk mengetahui, cara menjawab, cara menginterpretasi, dan cara menulis yang digunakan sebagai petunjuk untuk mengkaji berbagai aspek sesuai dengan proses dan prosedur penelitian ilmiah (Kitchin dan Tate, 2000).

Penelitian feminisme umumnya mengembangkan teknik baru dengan menggunakan metode tradisional secara reflektif dan representatif berkaitan dengan subjek yang sesuai dengan tujuan feminisme yaitu tentang perempuan. Kajian geografi feminisme pada dasarnya adalah upaya penguatan perempuan dalam memajukan geografi sebagai disiplin ilmu. Pengalaman dan persepsi perempuan yang berbeda atas laki-laki dan perluasan kesempatan perempuan untuk memperoleh pekerjaan dan pelayanan menjadi fokus kajian feminisme geografi. Peran perempuan sebagai ibu rumah tangga dihubungkan dengan struktur spatial, perencanaan, kebijakan, dan pola keterjangkauan terhadap transport dan pelayanan lainnya disamping perlindungan anak, biaya untuk memperoleh pekerjaan dan pemanfaatan sumberdaya lainnya oleh perempuan.

Kritik atas pendekatan geografi tentang perempuan pada mulanya adalah ketidaksetaraan jender. Dijelaskan ukuran dari konsep peran perempuan yang memusatkan pada perlawanan atas kekuatan laki-laki, mengenai hubungan perempuan dan laki-laki akhirnya muncul teori sosial yang statis dan peran perempuan secara pasif. Selanjutnya geografi mengenai perempuan memperlihatkan bagaimana menekankan keruangan dan membaginya kedalam konstruksi jarak mengenai posisi perempuan sehingga dapat menikmati kebebasan memilih pekerjaan dengan upah yang setara, juga tentang variasi dari relasi jender antar tempat (Katz, 2001). Sebagai kajian tentang kota yakni adanya perubahan untuk restrukturisasi kota yang mereduksi nilai ketidaksetaraan jender meliputi kualitas hidup, pelayanan, dan infrastruktur kota. 
Geograf feminisme aliran sosialis mengkaji kategori Marxian, teori untuk menjelaskan saling ketergantungan geografi, relasi jender, dan pembangunan ekonomi dibawah pengaruh paham kapitalis. Geografi feminisme sosialis mengkaji tentang jender dalam kota dan skala regional yang akhirnya menjadi dasar untuk mengkaji tentang perkembangan ekonomi dan ruang yang menekankan aspek geografi feminisme secara global sebagai capitalism (Domosh, 1999). Geograf feminis berupaya membuat jurnal tentang proses struktural fungsional dan strategi untuk mengelola dampak ekonomi kapitalis. Geograf feminisme meningkatkan perhatian pada perbedaan konstruksi dari relasi jender lintas ras, etnik, usia, agama, seksualitas, nasional, dan mencari relasi antara perempuan dan laki-laki dengan posisinya di berbagai kedudukan yang berbeda-beda. Geograf feminisme menggambarkan secara luas mengenai sekitar masalah sosial cultural, kemudian merambah pada teori yang masuk dalam psikoanalisa dan post strukturalis untuk mengetahui bagaimana relasi jender dalam konteks keruangan (Dixon dan Jones, 2006).

Perbedaan jender sebagai dasar analisis geografi feminisme mengkaitkan dimensi keruangan dalam kehidupan laki-laki dan perempuan lintas budaya, ekonomi, politik, dan lingkungan. Geografi feminis menjadi bagian penting guna memahami dan menganalisis relasi sosial mendasarkan perbedaan jender yang memunculkan budaya patriarki. Relasi jender sebagai konstruksi sosial budaya ternyata berdampak pada landscapes. Fenomena sosial secara intrinsik bermakna atau tergantung konsep, bagaimanapun, tidak untuk mendukung konten apa yang orang percaya, orang dapat bertindak terhadap satu sama lain atas dasar kesalahpahaman serta pemahaman (misalnya, membayangkan bahwa perbedaan jender dalam hal-hal seperti pekerjaan, rumah tangga, dan pekerjaan yang dibayar berdasarkan jender). Oleh karena itu untuk memahami bagaimana pria dan wanita menggunakan ruang yang berbeda, harus hadir untuk apa yang mereka pikirkan dan menganggap apa yang laki-laki dan perempuan harus lakukan terjadi secara 'alami'. Mengutip ini dalam penjelasan tentang perilaku yang membedakan laki-laki dengan perempuan, bukan berarti harus mendukung ide-ide bahwa laki-laki dan perempuan memang harus mengalami pembedaan dalam kotruksi sosial budaya Sayer (2006).

Jender sebagai dasar untuk membedakan laki-laki dengan perempuan dengan mempertimbangkan bentuk-bentuk analisis geografis feminis yang membahas dimensi spasial dari pengalaman hidup yang berbeda dari pria dan wanita dalam konteks budaya, ekonomi, politik, dan lingkungan. Analisis geografi feminisme diarahkan untuk analisis yang memahami jender sebagai hubungan sosial yang memiliki makna kesetaraan. Geografi feminisme, penekanan bergeser dari mempelajari pria dan wanita untuk memahami hubungan sosial yang menghubungkan laki-laki dan perempuan dalam kedudukan yang lebih kompleks. Bentuk yang paling hierarkis, hubungan laki-laki dan perempuan direalisasikan sebagai patriarki. Struktur patriarki sebagai struktur sosial secara spasial dan historis telah mampu memarjinalkan perempuan sebagai kelompok lemah sehingga memiliki posisi tawar yang rendah oleh dominasi laki-laki. Ketidaksetaraan jender dalam berbagai aktifitas kehidupan baahkan dalam kegiatan keilmuan telah mendorong geograf feminis untuk mengkaji bagaimana hubungan laki-laki dan perempuan dalam konteks spasial sehingga analisis kajian dapat dilakukan lebih detail guna pemecahan masalah. Pemecahan 
masalah yang dilakukan bukan mendasarkan pada generalisasi tetapi dengan pemikiran induktif sehingga detail analisis pemecahan masalah dapat tercapai. Geografi feminis memiliki harapan bahwa gambaran tentang fenomena relasi jender yang memiliki variasi dan distribusi sebagai identitas landscape. Identitas yang menjadi ciri baik pada lingkungan sekala mikro, meso, hingga makro antar warga masyarakat negara dan dunia.

\section{PENUTUP}

Tulisan ini mencoba mendiskusikan perdebatan positivistik dengan feminisme geografi mengingat sampai saat ini perdebatan dalam geografi sebagai sebuah keniscayaan. Keberlanjutan kehidupan manusia hingga abad 21 masih diwarnai dengan persoalan jender yang menempatkan perempuan pada konstruksi sosial budaya kurang menguntungkan. Keprihatinan ketidaksetaraan jender menarik untuk dikaji mengingat perbedaan relasi jender antar wilayah baik pada ranah, lokal, nasional dan global masih dapat dijumpai. Pengaruh lingkungan, tempat, variasi spatial merupakan variabel yang dapat dijadikan dasar untuk membangun Theory Feminist dengan paradigma geografi.

The geographic concepts of location, distance, connectivity, spatial variation, place, context and scale have all been enriched through the lens of feminist theory, which focuses on the difference that jender makes to a host of social processes. Feminist geographers transform the question, 'Where does work take place?', for instance, by the more targeted one, 'Who works where?' This more specific question can help researchers better understand the spatial dimensions of jender divisions of labor and their effects on women's economic wellbeing. Likewise, studies that look at connectivity have been enriched by an examination of the jendered character of the subjects undertaking the activity, whether in migration, commuting, or communication (Dixon and Jones, 2006)

\section{UCAPAN TERIMA KASIH}

Pada kesempatan ini penulis mengucapkan terima kasih kepada berbagai pihak yang telah membantu dalam penyusunan tulisan ini, baik selama proses penelusuran pustaka, diskusi, maupun penulisan.

\section{DAFTAR PUSTAKA}

Castree, N; Rogers,A; dan Sherman, D, 2005, Questioning Geography Fundamental Debate, Blackwell Publishig USA

Domosh, M, 1999, Sexing Feminist Geography, Progress In Human Geography. SAGE Publish London

Dixon, Deborah P. and John Paul Jones III, 2006, Feminist Geographies Of Difference, Relation, And Construction, dalam Approaches to Human Geography, SAGE Publish London.

Jonhston, 2000. The Dictionary of Human Gegraphy. Blackwell Publishers Ltd Oxford., London.

Katz, zc, 2001, All the World is Staged: aintelectuals and The Projects of Etnography Environment and Planning: Society and Place 10(5), 495-510 
Kitchin R and Nicholas J.T, 2000, Conducting Research in Human Geography: Theory, Methodology and Practice. Addison Wesley Longman, Singapore (Pte) Ltd., Singapore.

Kitchin, Rob, 2006. Positivistic Geographies and Spatial Science, dalam Approaches to Human Geography, SAGE Publish London.

Knox, PL dan Marston SA, 2004, Human Geography Places and Regions in Global Context, Pearson Edc, New Jersey

Koutopoulos, Kostis 2011, European Journal of Geography 1: 54-75, 2011. Association of European Geographers

Mc Dowell, Linda dan Massey, Doreen, 1996, A Woman's place?. dalam Human Geography An Essential Anthology, Agnew

Megawangi, Ratna, 1997. Jender Perspective in Early Childhood Care and Development in Indonesia. Report Submitted to The Consultative Group on Early Childhood Care and Development,

Nystuen, John D, 1999, Identification of Some Fundamental Spatial Concept dalam Agnew, John, Livingstone, David N, dan Rogers, Alisdair, 1999, Human Geography An Essential Anthology, Blackwell Publish, Oxford

Peter Hagget, 1983.Geography a Modern Synthesis, Harper And Row Publishers," New York

Sauer, Carl, 1999, The Morphology of Landscape dalam Agnew, John, Livingstone, David N, dan Rogers, Alisdair, 1999, Human Geography An Essential Anthology, Blackwell Publish, Oxford

Sayer, Andrew, 2006, Realism As A Basis For Knowing The World, dalam Approaches to Human Geography, SAGE Publish London.

Stuart Aitken and Gill Valentine, 2006, Ways of Knowing and Ways of doing geographic research, dalam Approaches to Human Geography, SAGE Publish London.

Whynne, C dan Hammond,.1979. Element of Human Geography, Oxford University Press. 